\title{
A Comparative Analysis of Cox's and Field's Explanations on Racial Inequality Root
}

\author{
Yiran Liu ${ }^{1, *}$ \\ ${ }^{1}$ School of Oregon State University, Corvallis, Oregon, 97331, the United States \\ *Corresponding author. Email:liuyira@oregonstate.edu
}

\begin{abstract}
In fact, the United States has been shrouded in the shadow of racism since its founding. Many American scholars have put forward their own views when they analyze race issues. In this paper, I aim to find the similarities as well as differences in the views of two famous scholars -Oliver Cromwell Cox and Barbara J. Fields- on the same issue of the root cause of racial inequality. Oliver Cox has a unique perspective compared with the academic mainstream at that time; he believed that capitalists or antagonisms lead to the problem with their colonial exploitation in the age of imperialism. As an influential anticipant in the intellectual movement of 'black Marxism', he provides researchers with Marxist view and new blood. In addition, Field points out that the element "history" holds a significant influence on the construction of concept of race; thus, the formation of race must be considered with its social and ideological context. Given the distincts between two famous scholars's standpoints on the root of racial inequality, I decide to build a comparison to explore to what extent they may agree with each other's point of view, and where their academic differences exist. After comparing the two scholars, I believe they would support that even the most striking physical characteristics do not stand for the concept "race". The biological differences are not meaningful when we focus on racial issue, although most people will locate it at appearances. And both would agree with taking capitalist power as the important role in racism. Having said that, there is also a difference existing in their views: Cox states that the class conflict between capitalist exploiters and the working class is the most contributing factor while Fields thinks that racism and related concepts are constituted by the dominant group and keep changing under different contexts in the U.S. In other words, history is the most essential factor. In conclusion, I hope that my results will encourage people to reexamine the root causes of racial problems during the special period of the "Freud event" in 2020.
\end{abstract}

Keywords: Oliver Cromwell Cox, Barbara J. Fields, racism, racial inequality, North America, colonism

\section{INTRODUCTION}

Today the United States is experiencing continuous turmoil due to the fermentation of the Freud event. In the national wave of protests the discrimination of colored people by the police system, people have refocused their attention on racial issues. In fact, racism has absorbed strong attention for many years. One way to obtain a clear understanding of racism is to re-examine related theories of the academic circle. Cox's book, Caste, Class and Race: A study in Social Dynamics, is a pillar of sociological analysis that opposes contemporary intellectual categorization. Cedric noted in his "Black Marxism": "And right at the beginning, you have to understand that he's very much against the idea of using Western conceptions of history, Western conceptions of social development, and applying them to the analysis of different societies." [1]. After industrialization in Europe, growing opposition between the capitalists and the working class has become a factor that must be considered when we reflect on social conflicts includes racism. Barbara. J. Fields is famous for her work, Slavery, Race and Ideology in the United States of America. However, she refuses to explain race by primarily using class. For decades, these two representative works have held huge influence and they are the main sources I focus on. Both figures provided us with examples of racial issues and related studies in the eyes of black scholars in the twentieth century and are worth analyzing. According to C.L.R James, “...the book created a sensation. Because, for the first time, a black man had made a scholarly and highly political attempt to organize and to go into problems which everybody knew were problems which concerned black people in the United States." [2]. Just like what Fields expresses in her article, 
"we cannot resolve the problem quantitatively, by the addition of example and counterexample. We can resolve it only by posing the question...", the most important thing is to explore the social reality reflected underlying the theories when we focus on their theories--What causes racism in their mind? Is this just discrimination against certain races? Or is this phenomenon determined by certain factors? Why were African blacks chosen as the source of labor finally instead of other race groups?

\section{METHODOLOGY}

I mainly adopt the method of "comparison" in this paper, and it is a fundamental research strategy. According to the article "Potentials and Limitations of Comparative Method", "...comparison plays an important part in the most diverse branches of the humanities and the social sciences alike" [2]. It can be seen as a method which systematically compare at least two cases to find out or analyze parallels and differences. Azarian also states that "Frequently, these cases are compared with regards to a specific phenomenon, like revolution, state formation processes, particular policies or types of organization, etc." [2]. So, in the case of my essay, comparative method is used to systematically analyze Cox's and Fields's attitudes towards the same question that the root cause(s) of racial issues in order to gain deeper findings and further conclusions. On the basis of this method, the main purpose of my article is to determine on which aspects the two authors (Cox and Fields) agree with each other and on which aspects they do not. I try to find the main similarities and differences in their answers to this same topic. To achieve that, I looked for and collected the parts of their articles discussing the same issues, then analyzed their respective attitudes, and finally conducted a thorough analysis to make all the similarities and differences become more intuitive.

\section{RESULTS AND DISCUSSION}

Based on Fields's works, she partially accepts Cox's view that external differences such as skin color do not determine whether a racial group would become the slave resource or an oppressed object. In the case of Virginia, she points out capitalist interests as well as political environment made black slaves gradually become the primary labor resource in America instead of other racial groups. In other words, the appearance characteristics do not make people believe that a racial group is inferior or should be born inferior. It is the economic and political benefits obtained from the continuous exploitation of a certain racial group for a long time, which constantly strengthens people's subconscious cognition of the appearance characteristics related to a specific race. When people's subconscious is deeply rooted, the bourgeoisie can reasonably continue to exploit the proletarian labor force from a moral standpoint. Nevertheless, Fields appears to reject Cox's idea that the essence of racial inequality is completely caused by oppression on the proletarian given by the bourgeois; she indicates that people "invent" racial ideologies to protect their own profits under several specific historical break points. So, racial discrimination is not primarily caused by the development of capitalism and the need of the bourgeoisie to expand their own interests, or the biggest invisible hand behind people's stereotypes about race is not capitalism, not planters, capitalists or politicians, but a stress response taken by people to defend their own interests in the face of some sudden historical events. This view means that the root of racial problems can not be contributed to white elites whether they premeditatedly convince the public to accept the images of other prominent racial groups that they hope the public to believe or not.

The core of Oliver Cromwell Cox and Barbara Jeanne Fields's arguments comes to the biggest factor that causes racial inequality and discrimination in North America. Barbara Fields points out that what gives the new concept about race within a scientific basis to the United States society should be the historical process. Although she stresses that racial ideology and slavery did not occur simultaneously in the U.S, race as a coherent ideology is still one of the consequent results of exclusion caused by slavery. According to Cox, racial injustice is caused by class exploitation and class conflicts. That means, the significance of confrontation between races has nothing to do with people's skin color or other physical differences, it is just the struggle between proletarian or working class who are undergoing exploitation and bourgeois who uphold the interest of capitalism after industrialization [1]. From his perspective, what happened in the U.S now and other racial movements could be considered as resistance to uneven distribution of power. The kind of protest against racial oppression is the surface form, and the actual core is the protest and challenge issued by the proletariat against the unfair distribution of resources, continuous exploitation, and the huge as well as enlarging wealth gap. I believe that Cox's understanding about racial problems can be explained in this way: racial conflict is not simply the result of a majority population oppressing other minorities, but a confrontation between a race group who monopolizes wealth or political power and another (or other) race group(s) who are forced to obey and make profits for the dominant group. Thus, in parts of Cox's view, racial exploitation is not established upon the boundary of color but has something to do with power relations relied on capitalist antagonism, and he focus a lot on the evolution of "class". In the Middle ages of Europe, "class rank" was substituted by the Three Estate System: the first estate was the clergy of the Catholic church, from archbishops and bishops down to parish priests; the second estate was the nobility such as state rulers, officers and knights (those who fought); and 
the rest but the majority was the third estate who provided labor force, including peasants, craftmen and businessmen[1]. This was the original order of social classes. But change emerged after industrial revolution and the collapse of traditional feudal autocracy: merely because the bourgeoisie is a class and no longer an industry, the bourgeoisie is forced to organize, no longer local, but national, and give its average interests a general form. By liberating private property from the community, the state has become an independent entity outside civil society [3]. Moreover, according to Adolph Reed Jr, Cox does not deny racism that exists among working-class whites. He believes that the observed open competition confrontation is generated and carefully maintained by both poor white and black exploiters. He recognized that elite whites defined the matrix of non elite whites to build their political institutions, and emphasized the ruling class basis of racism as part of his criticism of liberal scholars of racial relations, who theorized racial relations without considering capitalist political, economic and class dynamics.[1].

It is also worth noticing that Fields agrees that racism exists in the same race group and the same state, and leaded by profits. Not only in history, referring to the current caste system in India, we can confirm that the obvious hierarchy still legally exists among people of the same color in the same country. For the statement's first half, she may say, "Yes, sometimes racism occurred even among groups in the same color". She mentions that many records has made humanity learned again and again that shared color and nationality set no automatic limit to oppression", and "Greeks and Romans enslaved people of their own color... Europeans held other Europeans in both slavery and serfdom, and that the law in Tudor England provided for the enslavement of vagabonds" [3]. Massacres aiming at European Jews appeared as early as the Crusades in the Middle ages, and when the Black Death swept across Europe in the 14th century, Jews were also tortured by fire and other cruel executions because they were suspected of poisoning in the river. Such massacres against Jews occurred in many parts of Europe; she points out that during the Second World War, Jews and Romanians and German communists or Hitler's political opponents who were white Germans and owned pure "Aryan blood" were all prisoned in the concentration camps, and even the United States Supreme Court would be defined as racial groups. However, they are undoubtedly considered as white people in post-war world system, but they were not at that time. The changeable definition of white people and the inclusion of other ethnic groups can also well reflect the economic, political and cultural needs of different dominant groups in history. By the way, this is similar with Cedric Robinson's claim that the first modern racial subjects were not of African or Asian descent but European, including most notably the Catholic Irish, Slavs, Jews as well as countless others [3]. Obviously, the boundary or criteria to distinguish and define racial groups has kept changing.

Fields also agree that the more and more large-scale Triangle Trade had a connection with the planters' capitalist interests. Economic interests should indeed be taken into account but this is not the root. She states that morbid arithmetic did not change in Virginia until the 1660s. In 1676, a group of white freedmen issued the largest rebellion against the British authorities in American colony to protest planter domination of the colonial government, which made elites in America begin to realize that it would be too dangerous to use Europeans laborers and view African slaves as a safer and more reliable alternative to the increasing free armed white population [4]. African slaves were not the first choice for those planters in the new world until outer factors and the planters' economic conditions made them prefer doing so. Or we can say the appearance difference of the black group did not directly lead the planters and colonists to choose them as the most suitable objects for slavery and exploitation at the first time. It was not their skin color or body shape that brought disaster to them. But when other slave groups could not ensure that economic benefits of the colonists were stably maintained, black slaves officially and generally became the best choice in the hearts of the colonists. Here Fields makes the point that if Europeans and the white immigrants in the new world initially confirmed that those "Negros" belonged to an inferior race and they were natural slaves, they should prefer black slaves at the beginning. But this did not happen at first. So, this kind of shift that black slaves became the main force of plantation later was due to the change of capital market. This phenomenon reflected the historical development's trend. It was not white colonists who chose blacks as slaves and labor resources, but they had to do so to continue their capital interests.

The most significant difference of their arguments lies in the root cause of racial ideology. Although Fields agrees that capitalism determined the African slaves to become the mainstream of forced laborers, he denied that this was the only factor in the historical progress. All the specific historical aspects were added together to make racism sprout in the United States. For instance, the ideology of racial inferiority did not fully emerge until the incorporation of Africans and their descendants into a polity and society in which they lacked rights that others not only took it for granted but claimed as a matter of self-evident natural law[4]. From this perspective, we can understand the racial ideology used to exist in the North American colonies in this way: white people needed black laborers as their important resources, or the existence of black people is essential. But those black people with very limited rights could never be accepted by the white group and slavery was deemed to be very normal, then the concept of racial inferiority could justify this phenomenon: the black people's worse nature led to 
their social arrangements and they deserve these. And one thing that needs special attention is, Fields believes people's feeling about race is somewhat like the process of biological evolution. That means, racial ideologies did not naturally exist in our minds, just like people's aesthetic tendency and fashion trend, it is affected by the acquired social environment and is by no means invariable. Apparently, infants will not be racist, but it gradually evolved in accordance with the trend of historical developments. Just like a long time ago, the appearance of mankind was not what it is today; we gradually evolved in response to climate, environment and other factors to ensure our survivals and meet our needs. In addition, she claims that after the establishment of the United States, racial ideology provided the people of those republics based on radical theories of freedom and natural rights with the means to explain slavery [4]. This indicates that racism provides a perfect excuse or could be used as a propaganda for the coexistence of racial oppression and modern democracy or social independence. She also explicitly points out, "A racialist ideology harnessed to a ruling-class will, intention, and capacity to dominate both blacks and whites may be characterized by a patronizing tolerance, ...". Race has become part of American politics as well as a product of history. Nevertheless, Cox demonstrates a different point of view: although racial inferiority is also a kind of manmade tool, it is created by capitalist exploiters in order to keep their labor sources freely exploitable and the gap between rich and poor is the most fundamental cause of racial problems. When a racial group monopolizes political power or wealth in a country, it's highly likely that minorities would protest no matter they are able to fundamentally change the status of inequality or not. According to the Manifesto, the main confrontation in the capitalist society is the conflict between the two classes that are becoming increasingly unified nowadays: the bourgeoisie and the proletariat. The latter significantly homogenized in a world that 'national differences and antagonism between peoples are daily more and more vanishing [5]. This statement has implied the solution of racial problems in Cox's vision. However, Fields believes that "Class and race are concepts of a different order; they do not occupy the same analytical space, and thus cannot constitute explanatory alternatives to each other" [6]. In her opinion, if the exclusion or color bar caused by slavery and historical process between black and white could disappear, then the racial issues would not bother us anymore. So, all the troubles we have experienced today about race are bearing the consequences for the choices our humans have made again and again in history.

\section{CONCLUSION}

In general, both Cox and Fields deny that skin color or physical differences directly lead to racial issues. The physiological differences between different races are not the root cause of racial discrimination and inequality. Both admit that capitalist interests play a significant role in racial exploitation and racial ideologies including racial prejudice. However, Cox considers the class conflict between capitalist exploiters and the working class as the essence of racial problems. Racial contradiction is actually the confrontation between classes, that is to say, racial oppression is the appearance, and class exploitation is the essence. Today, the problem of black liberation is not a simple racial problem, but a class problem. The object it wants to resist is not white people, but the capitalist economic and political order represented by white people. And the horizontal confrontation between skin colors is transformed into vertical class opposition, and the ethnic conflict within the country is transformed into systematically uneven economic and political resources. Fields thinks that racism or racial ideologies are created and gradually evolved by dominant groups under historical frameworks in America to safeguard their interests. It is the development of the times that makes the situation gradually evolve into what it is today. It is the process of history and people's reactions to defend their own profits that jointly form the concept of race in modern society.

\section{REFERENCES}

[1] Reed Jr A. Race and class in the work of Oliver Cromwell Cox[J]. Monthly Review, 52(9): 23, 2001.

[2] Azarian R. Potentials and limitations of comparative method in social science[J]. International Journal of Humanities and Social Science, 1(4): 113-125, 2011.

[3] Marx K, Engels F. The German Ideology, transl. and edited by CJ Arthur[J]. 1974.

[4] James C L R. The class basis of the race question in the United States[J]. New Politics, 15(4): 48, 2016.

[5]Zittoun T, Gillespie A. Imagining the collective future: A sociocultural perspective[M]//magining collective futures. Palgrave Macmillan, Cham, 1537, 2018.

[6] Fields B J. Slavery, race and ideology in the United States of America[J]. New Left Review, 181(1): 95118, 1990. 